\title{
Phase II calm extension study: Coxsackievirus A21 delivered intratumorally to patients with advanced melanoma induces immune-cell infiltration in the tumor microenvironment
}

\author{
Robert HI Andtbacka ${ }^{1}$, Brendan D Curti ${ }^{2}$, Sigrun Hallmeyer ${ }^{3}$, Zipei Feng ${ }^{4}$, Christopher Paustian ${ }^{5}$, Carlo Bifulco ${ }^{6}$, \\ Bernard Fox ${ }^{4}$, Mark Grose ${ }^{7}$, Darren Shafren ${ }^{8^{*}}$
}

From 30th Annual Meeting and Associated Programs of the Society for Immunotherapy of Cancer (SITC 2015) National Harbor, MD, USA. 4-8 November 2015

\section{Background}

CAVATAK, an oncolytic immunotherapy, is a bioselected oncolytic strain of Coxsackievirus A21 (CVA21). Following intratumoral (IT) injection, CVA21 preferentially infects ICAM-1 expressing tumor cells, resulting in viral replication, cell lysis, and a systemic anti-tumor immune response. The Phase II CALM study investigated the efficacy and safety of IT CVA21 in pts with advanced melanoma. The primary endpoint of the study was achieved with 22 of 57 (38.6\%) evaluable pts with durable responses observed in both injected and uninjected melanoma metastases, suggesting the generation of significant host anti-tumor responses. Pre-clinical studies in an immune-competent mouse model of melanoma revealed that combinations of intratumoral CAVATAK and antiPD-1 or anti-CTLA-4 mAbs mediated significantly greater anti-tumor activity compared to use of either agent alone. Here we report on a continuation study aimed at understanding the immune mediated effects of CVA21.

\section{Methods}

To further elucidate the nature of the systemic antitumor responses, a CALM study (NCT01227551) extension cohort of $13 \mathrm{pts}$ received up to $3 \times 10^{8} \mathrm{TCID}_{50}$ CVA21 IT on study days $1,3,5$ and 8 and then every three weeks for a further 6 injections. Sequential tumor biopsies of both injected and uninjected lesions were monitored for levels of viral replication and evidence of

\footnotetext{
${ }^{8}$ Viralytics, Sydney, Australia

Full list of author information is available at the end of the article viral-induced immune activation within the tumor micro-environment. Serial serum samples were monitored for viral loads, anti-CVA21 neutralizing antibody $(\mathrm{nAb})$ and levels of immune-inflammatory cytokines.

\section{Results}

CVA21 administration was shown in 5 of 6 cases to induce increases in immune cell infiltrates within the tumor microenvironment, in particular $\mathrm{CD}^{+}$cells and increased expression of PD-L1 ${ }^{+}$cells as assessed by multispectral imaging. Reconstitution of immune cell infiltrates was observed in 4 of 4 of CVA21 treated lesions from patients failing treatment with single or doubleline immune-checkpoint blockade. Analysis of 4 preand post-treatment biopsy samples by NanoString digital RNA counting identified sizable up-regulation of a number of immune modulation elements, including a Th1gene shift, with increases in interferon-induced genes.

\section{Conclusions}

Intralesional administration of CVA21 can notably influence the dynamics of the tumor micro-environment as evidenced by increases in immune cell infiltrates and immune-related response genes. Our observation that CVA21 can reconstitute immune cell infiltrates in lesions resistant to immune-checkpoint blockade provides a strong rationale for the investigation of the sequential or concurrent administration of CVA21 and $\mathrm{T}$ cell checkpoint antibodies. A clinical trial combining CVA21 with anti-CTLA-4 is underway and other combination studies are planned. 


\section{Authors' details}

${ }^{1}$ University of Utah Huntsman Cancer Institute, Salt Lake City, UT, USA.

${ }^{2}$ Providence Cancer Center, Providence Portland Medical Center, Portland, OR, USA. ${ }^{3}$ Oncology Specialsists, Park Ridge, IL, USA. ${ }^{4}$ Earle A. Chiles Research Institute, Portland, OR, USA. ${ }^{5}$ Chiles Research Institute, Providence Cancer Center, Portland, OR, USA. ${ }^{6}$ Earle A. Chiles Research Institute, Providence Cancer Center, Portland, OR, USA. 'Viralytics Limited, Toronto, ON, Canada.

${ }^{8}$ Viralytics, Sydney, Australia.

Published: 4 November 2015

doi:10.1186/2051-1426-3-S2-P343

Cite this article as: Andtbacka et al.: Phase II calm extension study:

Coxsackievirus A21 delivered intratumorally to patients with advanced melanoma induces immune-cell infiltration in the tumor

microenvironment. Journal for Immunotherapy of Cancer 2015 3(Suppl 2): P343.

Submit your next manuscript to BioMed Central and take full advantage of:

- Convenient online submission

- Thorough peer review

- No space constraints or color figure charges

- Immediate publication on acceptance

- Inclusion in PubMed, CAS, Scopus and Google Scholar

- Research which is freely available for redistribution

Submit your manuscript at www.biomedcentral.com/submit 